Review Article

\title{
Role of Red Blood Cell Distribution Width (RDW) and Neutrophil Lymphocyte Ratio (NLR) in Diagnosis of Appendicitis in Paediatric Patients in H. Adam Malik Medan Central General Hospital
}

\author{
Desiree Anggia Paramita*, Erjan Fikri**, Zulfikar Lubis*** \\ *Surgery Resident of University of North Sumatra, \\ ** Paediatric Surgery Division of Faculty of Medicine University of North Sumatra - H. Adam Malik \\ Medan Central General Hospital, \\ *** Clinical Pathology Division of Faculty of Medicine University of North Sumatra
}

\section{INTRODUCTION}

Acute appendicitis in paediatric patient is among the causal of abdominal emergency which requires immediate operation (Victor, et al, 2012; Ballester et al., 2009; Huckins et al., 2013). The incidence of acute appendicitis in paediatric patient in the world ranges from 1 to $8 \%$ of all pediatric patients coming to the Emergency Department (ED) with acute abdominal pain (Jangra et al., 2013). Appendicitis is rare in children under 5 years, and very rare in the first year of life. In some instances, boys are more than girls around $55 \%$ to $65 \%$ of patients (Stevenson, Edward, 2003). The incidence rate of perforated appendicitis in the age group of children is about $30 \%$ to $40 \%$. Appendicitis in the neonate is very rare, and the surgeon should be careful of the accompanying conditions, such as Hirschsprung's disease and necrotic enterocolitis. (Stevenson, Edward, 2003).

Laboratory findings could help in diagnostic, but misinterpretation of laboratory values is still very common. A slight increase in leukocyte counts $(11,000-16,000 / \mathrm{mm} 3)$ was the most frequent finding. A significant increase in leukocyte counts indicates perforation. However, normal leukocyte counts also do not exclude an appendicitis (AlGaithy, 2012; Sahbaz et al., 2014; Sahu et al., 2014; Shawn, 2010; Xharra et al., 2012). One of the signs of inflammation are red blood cell distribution width (RDW) and neutrophil to lymphocyte ratio (NLR). Red blood cell distribution width (RDW) is a measurement of circulating erythrocyte size variations (Bujak K. et al., 2015). Children with appendicitis either perforated or not, have a significant increase in red blood cells compared to those without appendicitis ( $p<0.001$ ), but there is no significant difference in red blood cells in children with simple or perforation appendicitis $(\mathrm{p}=0.081)$ (Official Journal of the Japan Pediatric Society Pediatrics International (2016) 58, 202-205). Neutrophil and lymphocyte levels are derived from differential leukocytes count which is one of the components of routine blood examination. Various studies have shown an increase in neutrophil counts (neutrophilics) and a decrease in lymphocyte counts (lymphocytopenia) immediately after tissue injury (Riley LK and Rupert J. 2015). Based on Markar et al., lymphocytopenia that associated with a clinical history may have more precise accuracy than either WBC or CRP in the diagnosis of acute appendicitis. The aim of this study is to find out how the role of RDW and NLR counts in diagnosis of appendicitis severity towards paediatric patients in H. Adam Malik Medan General Hospital.

\section{METHODS}

The design of this study is a diagnostic study. Samples were collected through medical record with inclusion criterias were paediatric patients under 18 years old who suffered abdominal pain and diagnosed with appendicitis and had undergone appendectomy at H. Adam Malik Medan Central General Hospital during the period from 2012 to 2017. Patients with incomplete medical record were excluded. Sampling is done by consecutive sampling. The minimum number of samples calculated by the formula:

$$
n=\frac{(Z \alpha)^{2} \operatorname{Sen}(1-\operatorname{Sen})}{d^{2} P}
$$

Information:

$$
\begin{array}{ll}
\mathrm{n} & =\text { sample size } \\
\mathrm{Sen} & =\text { desired tool's sensitivity }=85 \%(\text { Satria }, 2015) \\
\mathrm{d} & =\text { precision }=\text { defined by researchers by } 15 \% \\
\mathrm{P} & =\text { prevalence of appendicitis in children }=4.5 \%
\end{array}
$$
(Jangra et al., 2013)

Based on the above formula, the minimum sample size of this study is 27 people.

The collected data will be presented descriptively in the frequency distribution table. The datas between haematologic components (RDW and NLR) and histopathologic results were then analyzed bivariately with Mann-Whitney test. Each parameter will be re-analyzed using the ROC curve to determine the cut-off point with sensitivity and specificity.

\section{RESULTS}


Desiree Anggia Paramita et.al / Role of Red Blood Cell Distribution Width (RDW) and Neutrophil Lymphocyte Ratio (NLR) in Diagnosis of Appendicitis in Paediatric Patients in H. Adam Malik Medan Central General Hospital

\section{Sample Characteristics}

A total of 138 patients consisting of $69(50 \%)$ boys were participated in the study. All of them had undergone appendectomy with pathologic results of complicated appendicitis in $93(67,4 \%)$ patients. The mean \pm SD of patient's age was $11.09 \pm 4.3$ years with most group among age 6 to 12 years as many as $65(47.1 \%)$ patients.

Table 1 Characteristics of Research Sample

\begin{tabular}{|c|c|c|c|}
\hline \multicolumn{2}{|l|}{ Characteristics } & $\begin{array}{l}\mathbf{n} \\
\text { Mea } \\
(\mathrm{Me}\end{array}$ & $\%$ \\
\hline \multirow[t]{2}{*}{ Sex } & Boys & 69 & 50 \\
\hline & Girls & 69 & 50 \\
\hline \multirow{2}{*}{$\begin{array}{l}\text { Diagnosed with } \\
\text { Appendicitis }\end{array}$} & Simple & 45 & 32.6 \\
\hline & Complicated & 93 & 67.4 \\
\hline \multirow[t]{4}{*}{ Age } & & 11. & \\
\hline & Infants and Toddlers $(<5$ yo $)$ & 17 & 12.3 \\
\hline & Children (6-12 yo) & 65 & 47.1 \\
\hline & Teenagers (13-18 yo) & 56 & 40.6 \\
\hline \multirow[t]{5}{*}{ Haematologic Parameters } & RDW (\%) & \multicolumn{2}{|c|}{$13.84 \pm 1.85(13.3)$} \\
\hline & Leukocytes $\left(\mathbf{x 1 0}^{3}\right)$ & \multicolumn{2}{|c|}{$15.91 \pm 6.99(14.53)$} \\
\hline & Neutrophils $\left(/ \mathrm{mm}^{3}\right)$ & \multicolumn{2}{|c|}{$75.83 \pm 11.80(14.53)$} \\
\hline & Lymphocytes $\left(/ \mathrm{mm}^{3}\right)$ & \multicolumn{2}{|c|}{$14.45 \pm 9.25(11.9)$} \\
\hline & NLR & \multicolumn{2}{|c|}{$7.8 \pm 5.33(6.58)$} \\
\hline
\end{tabular}

Table 2 Analysis of Various Hematologic Parameters and Diagnosis of Appendicitis

\begin{tabular}{llll}
\hline $\begin{array}{l}\text { Haematologic } \\
\text { Parameters }\end{array}$ & $\begin{array}{l}\text { Simple Appendicitis } \\
\text { Mean } \pm \text { SD (Median) }\end{array}$ & $\begin{array}{l}\text { Complicated } \\
\text { Appendicitis } \\
\text { Mean } \pm \text { SD (Median) }\end{array}$ & P* \\
\hline RDW & $13,70 \pm 1,59(13,4)$ & $13,91 \pm 1,96(13,3)$ & 0,764 \\
\hline Leukocyte $\left(\mathbf{x 1 0}^{3}\right)$ & $13,11 \pm 6,02(11,49)$ & $17,26 \pm 7,06(16,2)$ & $<0,0001$ \\
\multicolumn{1}{c}{ Neutrophils } & $69,77 \pm 13,33(72,8)$ & $78,76 \pm 9,79(81)$ & $<0,0001$ \\
\multicolumn{1}{c}{ Lymphocytes } & $18,59 \pm 10,76(15,6)$ & $12,45 \pm 7,73(10,7)$ & $<0,0001$ \\
NLR & $5,80 \pm 4,70(4,46)$ & $8,77 \pm 5,37(7,63)$ & $<0,0001$
\end{tabular}

* Mann-Whitney Test

In table 2, it can be seen that the hematologic parameter values of all leukocyte derivatives are statistically significantly different between simple appendicitis and complicated appendicitis. The RDW values between the two groups did not show values that statistically different.

\section{Role of RDW and NLR in Diagnosis of Appendicitis}

The values of RDW and NLR to the diagnosis of appendicitis were then analyzed using ROC to obtain the cut-off point with the highest sensitivity and specificity. The ROC curve and the diagnostic test values of both parameters are presented in Figures 1 and Table 3. 
Desiree Anggia Paramita et.al / Role of Red Blood Cell Distribution Width (RDW) and Neutrophil Lymphocyte Ratio (NLR) in Diagnosis of Appendicitis in Paediatric Patients in H. Adam Malik Medan Central General Hospital

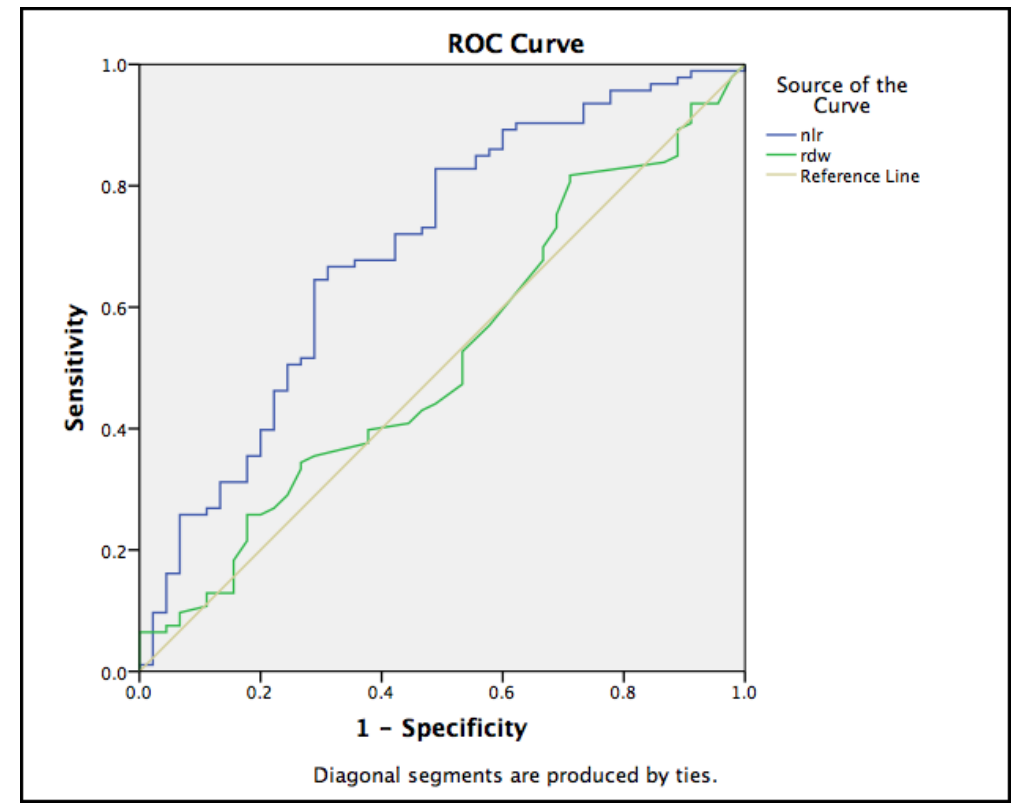

Figure 1. ROC Curve of RDW and NLR to Diagnosis of Appendicitis in Paediatric Patients

Table 3. Values of Area under the Curve of RDW and NLR Parameters to Diagnosis of Appendicitis in Paediatric Patients

\begin{tabular}{lllll}
\hline Parameters & $\begin{array}{l}\text { Area Under the Curve } \\
\text { (AUC) }\end{array}$ & p & Sensitivity & Specificity \\
\hline RDW & $51.6 \%$ & 0.764 & - & - \\
NLR & $69.6 \%$ & $<0.0001$ & $66.7 \%$ & $68.9 \%$ \\
\hline
\end{tabular}

On the ROC curve, the area under the curve of the RDW is $51.6 \%$ but that value does not provide a significant diagnostic value $(p=0.764)$.

On the ROC curve of the NLR, the area under the curve is $69.6 \%$ with a diagnostic value that statistically significant $(p$ $<0.0001)$. The highest sensitivity and specificity for the NLR are $66.7 \%$ and $68.9 \%$ at the cut-off point 5.95 .

\section{DISCUSSION}

This study assessed the relationship of RDW and NLR to the severity of appendicitis in paediatric patients. In the previous study, it was suggested that RDW played a role in the diagnosis of acute appendicitis in adults. Researchers only found a study of Bozlu et al (2016) who examined RDW in paediatric appendicitis. In that study, it was proposed that RDW was significantly different in paediatric patients with appendicitis compared to normal appendix. The value of RDW in paediatric patients with appendicitis found in that study was $13.63 \pm 1.08 \%$. However, the RDW value can not distinguish simple and complicated appendicitis $(p=0.081)$. That results are consistent with this study. The overall value of RDW of paediatric appendicitis in this study ranged from $13.84 \pm 1.85 \%$. However, after being analyzed with MannWhitney test, there is no significant differences between simple and complicated appendicitis $(13.7 \pm 1.59 \%$ and 13.91 $\pm 1.96 \%(p=0.764))$. The value of ROC analysis to RDW also showed insignificant results, ie with AUC 51.6\%. Thus, researchers were no longer looking for cutting point against
RDW to determine sensitivity and specificity.

Yazici in 2010 examined the role of NLR in the diagnosis of appendicitis in paediatric patients and found that a NLR score greater than 3.5 is a more accurate as a predictor factor when compared with total leukocytes. In this study the researchers found the appropriate value of NLR in all appendicitis patients is $7.8 \pm 5.33$. However, there was no previous research has determined the value of NLR that distinguished simple and complicated appendicitis. In this study the researchers found that the NLR values were also statistically different in each group, ie $5.80 \pm 4.7$ and $8.77 \pm 5.37(\mathrm{p}<0.0001)$. The researchers then performed $\mathrm{ROC}$ test at that value and obtained the area under the curve (AUC) 69.6\%. The highest sensitivity and specificity for the NLR were $66.7 \%$ and $68.9 \%$ at the cut-off point 5.95. Thus, it can be concluded that the value of NLR is a promising predictive factor not only for diagnosing appendicitis, but also for determining the severity of appendicitis in paediatric patients.

\section{CONCLUSION}

RDW values were not statistically significant in the diagnosis of appendicitis in paediatric patients. The researchers found that the NLR values were statistically different in the simple and complicated appendicitis group, ie, $5.80 \pm 4.7$ and $8.77 \pm$ 5.37 ( $p<0.0001)$. The ROC test value shows the area under the curve (AUC) of $69.6 \%$. The highest sensitivity and specificity values for the NLR were $66.7 \%$ and $68.9 \%$ at the cut-off point 5.95. Thus, it can be concluded that the value of 
Desiree Anggia Paramita et.al / Role of Red Blood Cell Distribution Width (RDW) and Neutrophil Lymphocyte Ratio (NLR) in Diagnosis of Appendicitis in Paediatric Patients in H. Adam Malik Medan Central General Hospital

NLR is a promising predictive factor not only for diagnosing appendicitis, but also for determining the severity of appendicitis in paediatric patients.

\section{REFERENCES}

[1] Apendisitis. In DynaMed [database online]. EBSCO Information Services. http://search.ebscohost.com/login. aspx ?direct $=$ true $\&$ site $=$ DynaMed $\& i d=115548$. Updated November 21, 20113. Accesssed November 28, 2013.

[2] Aschcraft, K.W., Pediatric Surgery, 3 th Edition, WB Saunders Company, Philadelpia-NewYork-LondonTokyo, 2000: p. 406-21.

[3] Azez AK, Kazim TJ, Alkareem MFA. Abnormal Urinalysis in Acute Apendisitis. Diyala Journal of Medicine. Vol. 7, Issue 1, Desember 2014.

[4] Ballester JCA, Sanchez AG, Ballester F. Epidemiology of appendectomy and Apendisitis in the Valencian community (Spain) 1998-2007. Dig Surg. 2009;26:406412. doi 10.1159/000235956.

[5] Bhasin SK et al. Vermiform Appendix and Acute Appendicitis. JK Science. Vol. 9 No. 4, OctoberDecember 2007.

[6] Bhatt M. Prospective validation of the pediatric Apendisitis score in a Canadian pediatric emergency department. Montreal. Thesis, McGill University. 2008.

[7] Bujak K. Et al. 2015. The Prognostic Role of Red Blood Cell Distribution Width in Coronary Artery Disease: A Review of the Pathophysiology. PMC4563066.

[8] Craig S. Apendisitis. Medscape reference. http://emedicine.medscape.com/article/ 773895. Updated November 25, 2013.

[9] Eylin. Karakteristik pasien dan diagnosis histologi pada kasus apendisitis berdasarkan data registrasi depatremen patologi anatomi FKUI RSUPN Cipto Mangunkusumo pada tahun 2003-2007. Jakarta. Skripsi, FK Universitas Indonesia. 2009.

[10] Goldman RD, Carter S, Stephens D, et al. Prospective validation of pediatric Apendisitis score. J Pediatr. 2008; 153:278-282. doi 10.1016/j. jpeds.2008.01.033.

[11] Goodman, D. (1995). Use of the neutrophil: lymphocyte ratio in the diagnosis of apendisitis. The American Surgeon, 400-403.

[12] Goulder F and Simpson T. Pediatric Apendisitis score: a retrospective analysis. J Indian Assoc Pediatr Surg. 2008;13(4)125-127. doi 10.4103/0971-9261.44761.

[13] Gulcin Bozlu,et al. Diagnostic value of red blood cell distribution width in pediatric acute apendisitis. Journal of the Japan Pediatric society Pediatrics International (2016) 58, 202-5)

[14]Hermanto : Apendisitis pada Anak , emergency department diagnosis \& management. Artikel Kesehatan , 2011.

[15] Huckins, David S, Simon, et al. A novel biomarker panel to rule out acute Apendisitis in pediatric patients with abdominal pain. The Am $J$ of Emerg Med.2013;31(9):1368-1375.http://search.proquest.com/ docview/1430634945? accountid=50257.

[16] Ishizuka, M., Shimizu, T., \& Kubota, K. (2012). Neutrophil-to-lymphocyte ratio has a close association with gangrenous apendisitis in patients undergoing appendectomy. International Surgery, 97(4), 299-304.

[17] Ivan CP. Karakteristik penderita apendisitis di RSUP Haji Adam Malik Medan pada tahun 2009. http://repository.usu.ac.id/handle/123456789/21908. Diakses pada tanggal 27 November 2013.

[18] Jangra, Babita, Jangra, et al. Seasonal and day of weak variations in acute Apendisitis in north Indian children. $J$ of Indian Association of Pediatr Surgeon 2013;18(1):423.http://search.proquest.com/docview/1317919106? accountid $=50257$.

[19] Kahramanca S, et al. Neutrophil to lymphocyte ratio as a predictor of acute apendisitis. Ulus Travma Acil Cerr Derg January. 2014. Vol 20 No 1.

[20] Kahramanca, S., Ozgehan, G., Seker, D., Gokce, E. I., Seker, G., Tunc, G., ... Kargici, H. (2014). Neutrophil-tolymphocyte ratio as a predictor of acute apendisitis. Ulus Travma Acil Cerrahi Derg, 20(1), 19-22.

[21] Kamran H, Naveed D, Nazir A, Hameed M, Ahmed M, Khan U. Role of total leukocyte count in diagnosis of acute apendisitis. J Ayub Med Coll Abbottabad 2008; 20:70-1.

[22] Krishnan S. 2010. Jumlah leukosit pada pasien apendisitis akut di RSUP HajiAdam Malik Medan pada tahun 2009 [Skripsi]. Medan :Universitas Sumatera Utara. Fakultas Kedokteran.

[23] Lateef AU, Arshad AR, Misbah J, Hamayun M. Role of leukocyte count in the diagnosis of acute apendisitis. Gomal J of Medical Sciences 2009; 7:140-2.

[24]Lee SL. Vermiform apendix. Medscape reference. http://emedicine.medscape.com/ article/195652-overview. Updated October 18, 2013. Accessed December 2, 2013.

[25] Minkes RK. Pediatric Apendisitis. Medscape reference. http://emedicine.medscape. com/article/926795. Updated April 25, 2013.

[26] Obinna O, Adibe, Oliver J, et al. Severity of Apendisitis corelates with the pediatric Apendisitis score. Pediatr Surg Int. 2011;27:655-8. Doi 10.1007/s00383-010-27449.

[27] Riley LK and Rupert J. Evaluation of Patients with Leukocytosis. Am Fam Physician. 2015 Dec 1;92 (11): 1004-1011.

[28] Robbins and Cotran : Pathologic Basic of Disease, 8th ed Philadelpia : by Saunders, an imprint of Elsevier Inc , 2004

[29] Santacrose R., Craig S. 2006. Apendisitis. http://www.emedicine.com/topic41. 30 Desember 2011

[30] Saucier A, Eunice Y, Huang, et al. Prospective evaluation of a clinical pathway for suspected Apendisitis. 
Desiree Anggia Paramita et.al / Role of Red Blood Cell Distribution Width (RDW) and Neutrophil Lymphocyte Ratio

(NLR) in Diagnosis of Appendicitis in Paediatric Patients in H. Adam Malik Medan Central General Hospital

Pediatrics. 2013;e88-e95. doi 10.1542/peds.2013-2208.

[31] Sabiston, D.C.,Jr, M.D.2008. Sabiston Buku Ajar Bedah. Jakarta: EGC

[32] Schwartz SI : Apendix, in Principles of Surgery, 8th ed. New York : Mc Graw Hill Inc, 2009 : 1307-30

[33] Stankovic, N., Stanojevic, I., Djordjevic, D., Kostic, Z., Udovicic, I., Milickovic, M., ... Surbatovic, M. (2016). Neutrophil-to-lymphocyte ratio in pediatric acute apendisitis. Vojnosanitetski Pregled, (0), 210.

[34] Urovitz EB. Leukopenia. Family \& Community Medicine University of Toronto. February 2013.)

[35] Victor Y, Kong, Bulajic B, et al. Acute Apendisitis in a developing country. World J Surg. 2012;36:2068-2071. doi 10.1007/s00268-012-1629-9.

[36] Viel, Alain. Structure and Physiology of Red Blood Cells. Harvard University. 2009.

[37] Wesson DE, Singer JI, Wiley JF. Acute Apendisitis in children. http://www. uptodate.com/contents/acuteApendisitis-in-children-cli... Updated July 25, 2014. Accesssed August 07, 20 